\title{
Calpionellid biostratigraphy of the Upper Tithonian-Upper Valanginian interval in Western Sicily (Italy)
}

\author{
Gloria Andreini $^{1 *}$, Jesús E. CARACuel ${ }^{2} \&$ Guido Parisi $^{1}$ \\ Keywords: Calpionellids, Tithonian, Valanginian, Western Sicily, biostratigraphy, taxonomy
}

\begin{abstract}
A revision of the calpionellid bio-chronostratigraphy in Western Sicily (Italy) was carried out, in order to update the taxonomy of this group, through the identification of some genera (Borziella, Longicollaria, Chitinoidella, Dobeniella, Sturiella, Borzaiella and Praecalpionellites) and species (Remaniella catalanoi POP, Remaniella duranddelgai POP, Remaniella colomi POP, Remaniella borzai POP, Remaniella filipescui POP) recorded for the first time in the area. The studied sections, belonging to the Trapanese and Saccense Domains (Western Sicily), include at the base the upper portion of the Rosso Ammonitico Unit (Upper Tithonian), followed by the Lattimusa Formation (Lower Cretaceous). The quantitative and biostratigraphic analysis of the calpionellid assemblages allowed us to identify 13 assemblages and to define some important bioevents for the Upper Tithonian-Valangianian interval. The recorded calpionellid bioevents allowed us to recognize Zone/Subzone schema, which have been correlated with the bio-chronostratigraphy previously proposed for the Western Tethys.
\end{abstract}

\section{RIASSUNTO}

Una revisione della biostratigrafia a Calpionellidi in sezioni della Sicilia Occidentale ha permesso di aggiornare la tassonomia di questo gruppo, con l'identificazione di generi (Borziella, Longicollaria, Chitinoidella, Dobeniella, Sturiella, Borzaiella e Praecalpionellites) e delle specie (Remaniella catalanoi Pop, Remaniella duranddelgai Pop, Remaniella colomi Pop, Remaniella borzai Pop, Remaniella filipescui Pop) rinvenuti per la prima volta in Sicilia Occidentale. Le sezioni studiate appartengono ai Domini Saccense e Trapanese. Tali sezioni sono caratterizzate alla base dell' Unità Rosso Ammonitico e successivamente dalla Formazione della Lattimusa. L'analisi biostratigrafica e quantitativa delle associazioni a Calpionellidi ha permesso di identificare 13 associazioni e di caratterizzare alcuni eventi principali, nell'intervallo Titoniano superiore-Valanginiano. I bioeventi registrati hanno consentito di riconoscere Zone e Sottozone, che sono state corrrelate con gli schemi biostratigrafici proposti in precedenza per la Tetide occidenatale..

\section{Introduction}

The calpionellids, calcareous microplankton protists, characterize the Tithonian-Hauterivian interval in the Tethyan realm, with a potential biostratigraphic application from the Upper Tithonian to the Upper Valanginian. Apart from the pioneer works by Deflandre (1936), Colom (1948), Andrusov (1950), Pokorny (1954) and Bonet (1956), a standard calpionellid zonation was first established in the $2^{\text {nd }}$ Conference on Planktonic Organism in 1970 in Rome (Allemann et al. 1971). In the 1980`s, at the Sümeg Meeting (Hungary), Remane et al. (1986) together with Trejo (1980) and Altiner \& Özkan (1991), proposed an updated bio-cronostratigraphic scheme at the Subzonal level. Recently, Pop (1994b, 1996), Oloriz et al. (1995),
Grün \& Blau (1997) and Reháková \& Michalík (1997) worked out an alternative calpionellid Subzonal scheme, although detailed long-distance bio-chronostratigraphic correlations are still unclear.

The Jurassic-Cretaceous pelagic successions in Western Sicily are dominated by the typical condensed "Rosso Ammonitico" Unit, overlain by the expanded "Calcari a Calpionelle" Unit, locally named Lattimusa Formation (equivalent to the Southalpina Maiolica Formation). Some studies on calpionellid biostratigraphy have been carried out in Tithonian to Valanginian successions of Western Sicily during the 1960's and 1970’s (Catalano \& Lima 1964; Catalano 1965; Catalano \& Li-

\footnotetext{
1 Dipartimento di Scienze della Terra, Università Perugia, Piazza Università 06100, Perugia, Italy.

2 Departamento Ciencias de la Terra y del Medio ambiente, Universidad Alicante, Apdo. 99 San Vicente del Raspeig 03080, Alicante, Spain.

*Corresponding author: G. Andreini. E-mail: paleodot@unipg.it
} 


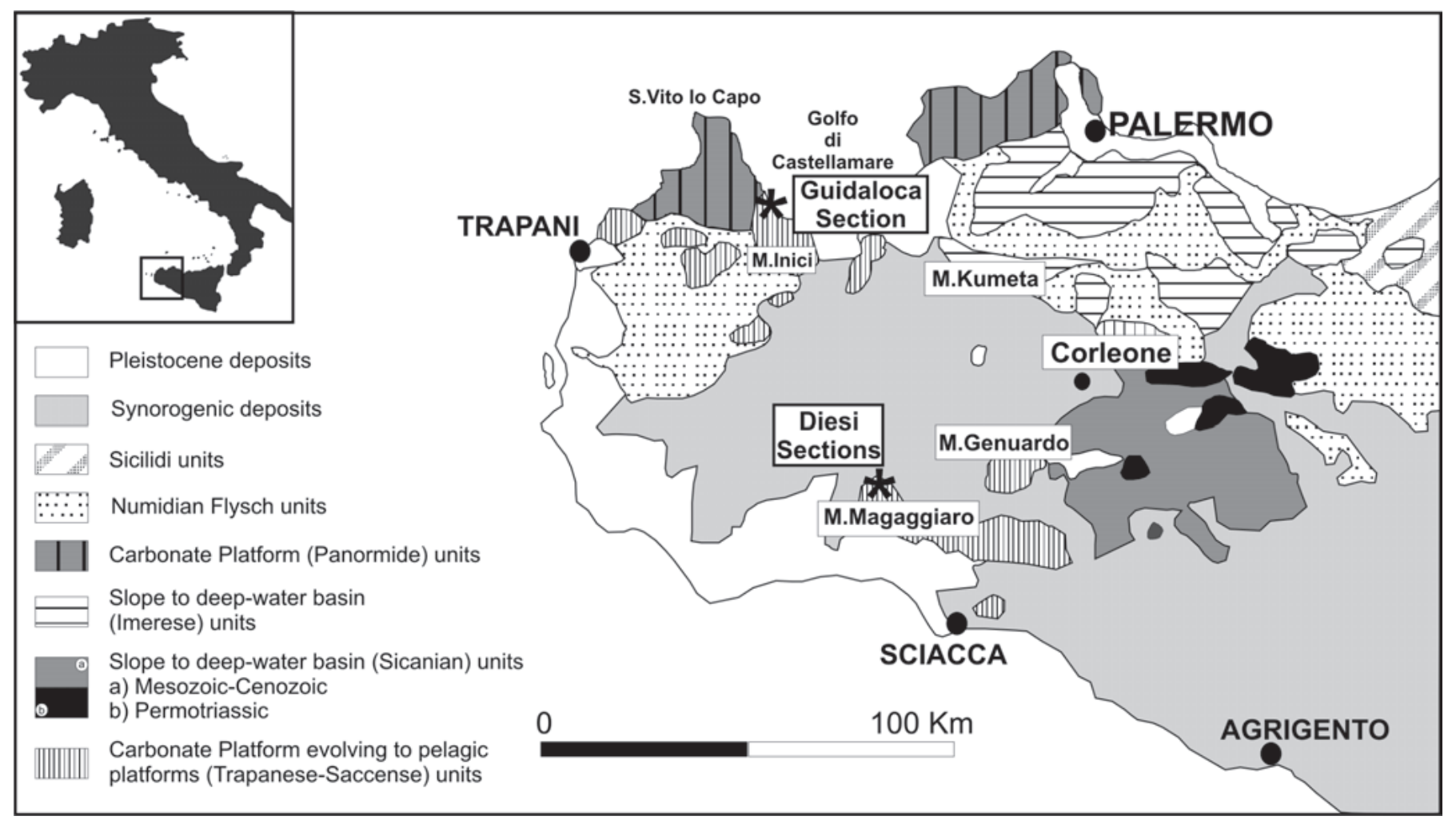

Fig. 1. Geological map of Western Sicily (Italy), with location of the studied sections (after di Stefano 2002, modified).

guori 1971) and recently by Cecca et al. (2001) and Marino et al. (2004).

The present work deals with the revision of the calpionellid taxonomy, considering recently defined genera and species, in order to update the bio-chronostratigraphy for Western Sicily.

\section{Geological and stratigraphic setting}

During the Middle Jurassic, part of the Sicilian-Tunisian Platform drowned, due to active listric faults (di Stefano 2002). Consequently, the area was structured in a complex system of small basins, swells and tilted blocks, which characterize the Panormide, Trapanese, Saccense and Hyblean palaeogeographic domains. In the Trapanese and Saccense Domains, the Jurassic succession starts with shallow water carbonates of the Inici Formation, followed by a regional drowning unconformity during most of the Pliensbachian. Later on, during the Toarcian and Middle-Upper Jurassic, the sedimentation is mainly represented by condensed limestones, Rosso Ammonitico, including, sometimes, siliceous marls. In the uppermost Tithonian, started the deposition of the Lattimusa Formation, equivalent to the Southalpina and Northapenninic Maiolica Formation (Fm.) in the Trapanese Domain, the Rosso Ammonitico Unit is subdivided into two members, separated by a siliceous radiolaritic interval, while in the Saccense Domain this sili- ceous interval is absent (di Stefano \& Mindszenty 2000; Chiari et al. 2004; Marino et al. 2004).

\section{Studied sections}

The studied sections belong to the Trapanese (Guidaloca section) and Saccense (Diesi sections) Domains. The Guidaloca area has been interpreted, palaeogeographically, as the upper part of a talus related to the structural high of the Monte Inici area (Caracuel et al. 2002; Cecca et al. 2001), while the Diesi area belongs to a complex horst-graben system related to the structural high of the Monte Magaggiaro (di Stefano et al. 2002; Marino et al. 2004) (Fig. 1).

\section{Guidaloca section}

The section crops out along the Guidaloca Beach, $3 \mathrm{~km}$ from Castellamare del Golfo (Fig. 1). The Upper Jurassic succession lies unconformably over the Inici Fm. and is composed by 12.5 $\mathrm{m}$ of alternating cherty marly/calcarenitic layers, followed by 20 m of Kimmeridgian-Tithonian p.p. marly Rosso Ammonitico (Caracuel et al. 2002). The Rosso Ammonitico Unit is overlain by more than $90 \mathrm{~m}$ of white rhytmic limestone with chert, rich in calpionellids (Lattimusa Fm.), dated as latest Tithonian to Valanginian (Fig. 2). 


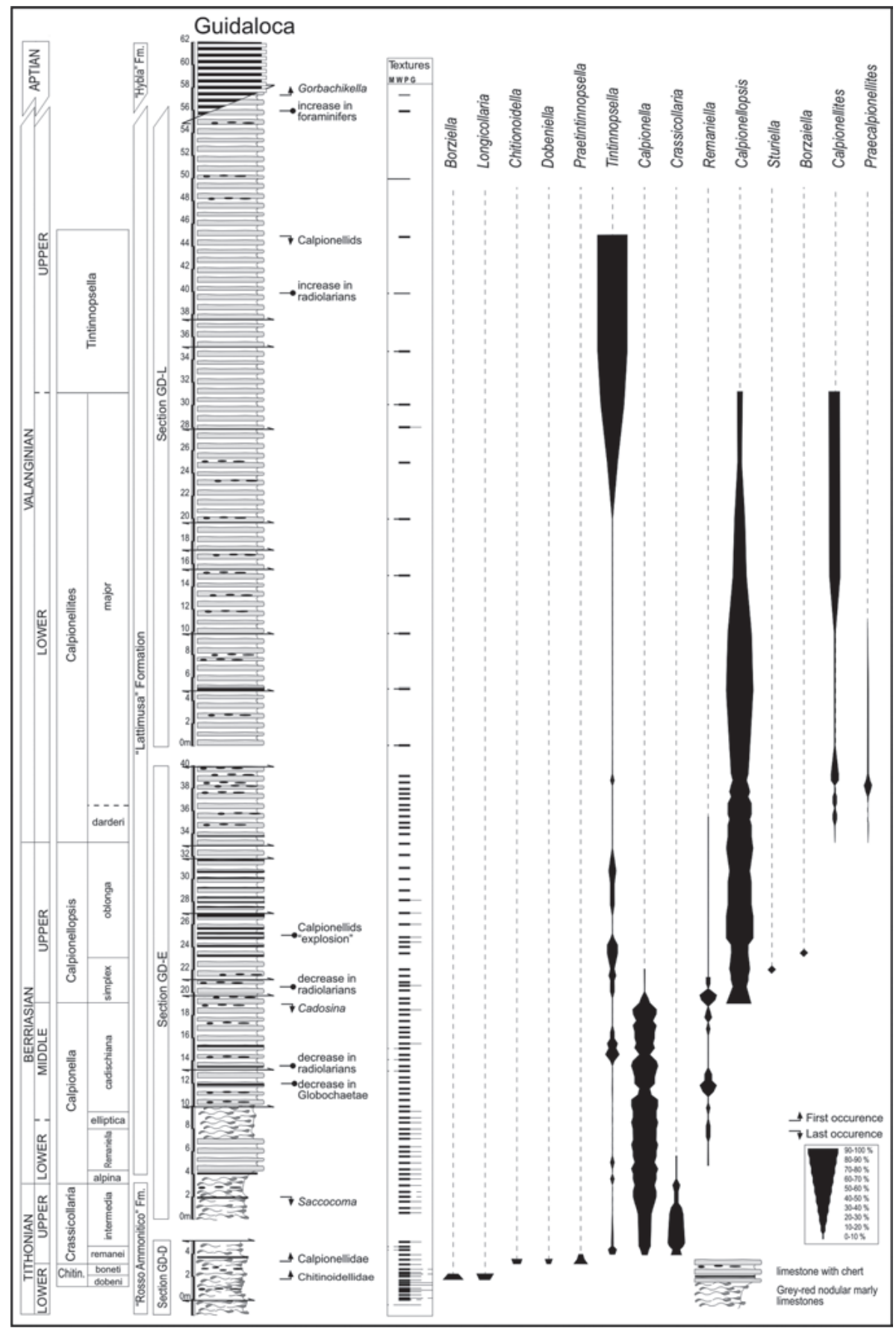

Fig. 2. Age, lithostratigraphy and calpionellid biostratigraphy of the Guidaloca section and quantitative distribution of the recorded calpionellid genera.
The lower part of this section (Rosso Ammonitico Unit) is ammonite-poor, and it was dated by calcareous nannofossils, calpionellids and radiolarians as Lower Tithonian p.p. uppermost Tithonian.

Textures are peloidal wackestones and packstones enriched in Saccocoma, radiolarians, calpionellids, Globochaeta, Cadosina, Stomiosphaera, with subordinate thin-shelled bivalves ("filaments"), and benthic foraminifers (mainly Lenticuli- na). Bioturbation by Thalassinoides, small Chondrites and Planolites is widespread at the top of the nodular intervals.

This Rosso Ammonitico Unit evolves gradually to more than $90 \mathrm{~m}$ of monotonous white cherty limestones in thin irregular beds (Lattimusa Fm.). No trace fossils have been recognized and macroinvertebrates are scarce, only represented by ammonites, aptychi, brachiopods and echinoderm fragments. Textures range from calpionellid-bearing mudstones to wack- 

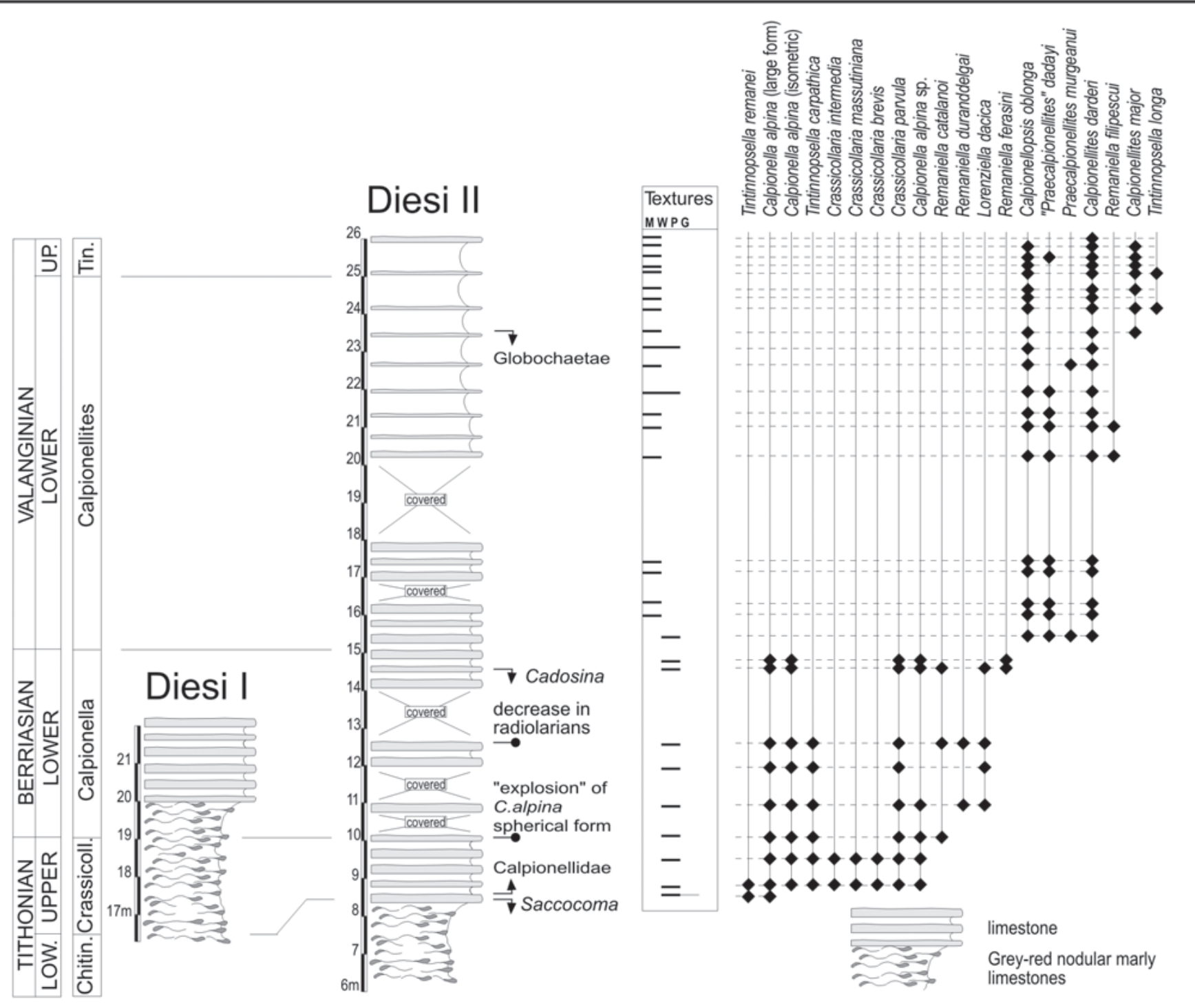

Fig. 3. Age, lithostratigraphy and calpionellid biostratigraphy of the Diesi I and II sections and distribution of the recorded taxa.

stones (occasionally packstones) with radiolarians, globochaetes, cadosinas, "filaments" and foraminifers. On the base of calpionellid biostratigraphy, this unit encompasses the Uppermost Tithonian-Valanginian interval. Upward, the Lattimusa Fm. is tectonically overlain by the Hybla Fm. (Barremian-Albian).

\section{Diesi sections}

The Mesozoic succession in the Saccense Domain starts with several thousand metres of platform limestone and dolostone of the Late Triassic, formally named Sciacca Fm. (same as the Gela Fm. of the Hyblean Plateau). It is overlain by 200-300 m of shallow water carbonates of Early Jurassic age (Inici Fm.)
(Schmidt di Frieberg 1965; Ronchi et al. 2000). This unit is followed upward by the Buccheri Fm. (or Rosso Ammonitico Unit), made of condensed pelagites with abundant ammonites, which range from the Lower Jurassic to the Lower Tithonian. Similarly to the Guidaloca area, during the interval from the latest Jurassic to the Early Cretaceous, the Lattimusa Fm replaces the Buccheri Fm.

The succession is well exposed in the quarry at Contrada Diesi, near Sciacca, on the northernslope of Mt. Magaggiaro (Fig. 1). Two complementary sections were studied, characterized at the base by a grey-red nodular limestone (Rosso Ammonitico Unit) reduced in thickness, and followed by a thin, white well-bedded limestone (Lattimusa Fm.) in the upper part (Fig. 3). As a whole, this interval includes wackestone and 
mudstone with abundant calpionellids, foraminifers (textulariids and valvulinids), rare radiolarians, echinoid fragments and some ammonites. Saccocoma disappears at the base of this unit, during the uppermost Tithonian, close to the first occurrence (FO) of spherical forms of Calpionella alpina LORENZ (Marino et al. 2004). The nodular limestones are packstones with crinoidal debris, internal moulds of ammonites and aptychi. Nodules are made of mudstone/wackestone, often with stylolithic contact. Microfossils include foraminifers, mainly Lenticulina sp. and Spirillina sp., radiolarians, Cadosinids and Saccocoma sp.

\section{Calpionellid assemblages}

The analysis of the taxon distribution in the studied sections, and the quantitative analyses of the calpionellid assemblages in the Guidaloca section (Fig. 4), allow us to identify 13 successive assemblages from the uppermost Lower Tithonian to the Valanginian. The thin sections were studied counting all the specimens in a constant area of $6 \mathrm{~cm}^{2}$ to obtain statistical significance. The observations are made using $\mathrm{a} \times 100$ magnification.

\section{Assemblage I}

The calpionellid assemblages in the lower part of the studied interval are characterized by scarcity and low diversity (5\% of the microbiofacies). The first appearance of calpionellids is characterized by rare presence of chitinous specimens of Borziella slovenica (BoRZA) (Pl. I: figs. 1a, b) and Longicollaria cf. dobeni (BORZA) (Pl. I: figs. 2a, b).

\section{Assemblage II}

The assemblage is characterized by the first occurence of chitinous specimens with composite collar, represented by Dobeniella bermudezi (FURRAZOLA-BERMúdEZ) (Pl. I: figs. 6a, b; 7a, b) and Dobeniella cubensis (FURRAZOLA-BERMúdEZ) (Pl. I: figs. 8a, b); there is also Chitinoidella boneti DoBEN (Pl. I: figs. $3 a, b ; 4 a, b ; 5 a, b)$.

\section{Assemblage III}

This is the first assemblage with hyaline calpionellids. It is characterized by rare Praetintinnopsella andrusovi BORZA (Pl. I: fig. 9), low diversified Crassicollaria (group intermedia (DURAND-DelgA)-brevis REMANE), small Calpionella alpina LoRENZ (Pl. I: fig. 10) and small, badly preserved Tintinnopsella, doubtfully assigned to Tintinnopsella carpathica (MurgeAnu \& Filipescu)-remanei (BorzA). Due to the bad preservation of delicate parts as collars, typical for the condensed nodular limestones of the Rosso Ammmonitico facies, it is difficult to make a species-based characterization of Crassicollaria and Tintinnopsella. Moreover the identification of the double-walled tests (hyaline and microgranulare) of Praetintinnopsella is also difficult (Olóriz et al. 1995).

\section{Assemblage IV}

A sharp increase in abundance and diversity (both at the genus and species level) is registered starting from this assemblage and moving upward (70\% of the microbiofacies). This assemblage is characterized by abundant large forms of Calpionella alpina LORENZ (Pl. I: fig. 13), Calpionella sp. (Pl. I: figs. 14, 15, 33) and, in the middle part, by the occurrence of small spherical forms of the C. alpina LoRENZ (Pl. I: figs. 11, 12). According to Olóriz et al. (1995), there is a significant record of Calpionella with lenght/width ratio ranging from 1.25 to 1.35 , referred to as Calpionella homeomorph elliptica. These forms were already noted by Remane (1985) along the boundary of the A/B Zones, and by Altiner \& Özkan (1991), who called them Calpionella sp. as a transitional form beetwen C. alpina LORENZ and C. elliptica CADISCH. The genus Crassicollaria is diverse, including Cr. intermedia (DURAND-Delga) (Pl. I: figs. 28, 29), Cr. brevis REMANE (Pl. I: figs. 19, 20), Cr. colomi DoBEN (Pl. I: figs. 26, 27), Cr. massutiniana (COLOM) (Pl. I: figs. 23-25) and Cr. parvula REMANE (Pl. I: figs. 21, 22), decreasing from common at the base to rare at the top of the assemblage. The assemblage is also composed by rare T. carpathica (MuRGEANU \& FiliPESCU) (Pl. I: figs. 16-18; Pl. II: figs. 14, 15).

\section{Assemblage $V$}

This assemblage is characterized by the explosion in abundance (Allemann et al. 1971) of C. alpina LoRENZ, with a variable morphology, but dominated by small spherical forms, which define the base of this assemblage. Tintinnopsella carpathica (MURGEANU \& FILIPESCU) is still present in this assemblage, and Calpionella sp. is frequent. The genus Crassicollaria is represented only by $C r$. parvula REMANE, that disappears in the uppermost part of the assemblage.

\section{Assemblage VI}

The base of this assemblage is marked by the FO of the genus Remaniella (well preserved specimens, although rare) with the species $R$. catalanoi PoP (Pl. I: figs. 32a, b; Pl. II: figs. 4a, b) and $R$. ferasini (CATAlano) (Pl. I: figs. 30a, b; 31a, b). The genus Remaniella is also represented by $R$. duranddelgai POP (Pl. II: figs. 3a, b; 6a, b) in the uppermost part. Moreover, the assemblage is characterized by common $C$. alpina LoRENZ (small spherical forms), Calpionella $\mathrm{sp}$. and rare $T$. carpathica (Murgeanu \& Filipescu).

\section{Assemblage VII}

The base is defined by the apperance of Calpionella elliptica CADISCH (Pl. II: figs. 1, 2) and this assemblage is clearly dominated by $C$. elliptica $\mathrm{CADISCH}$ together with $C$. alpina LORENZ (including abundant small spherical forms), very rare $C$. sp., and rare $T$. carpathica (MURGEANU \& FILIPESCU), and the genus Remaniella with $R$. duranddelgai PoP, $R$. catalanoi Pop and $R$. ferasini (CATALANO). 


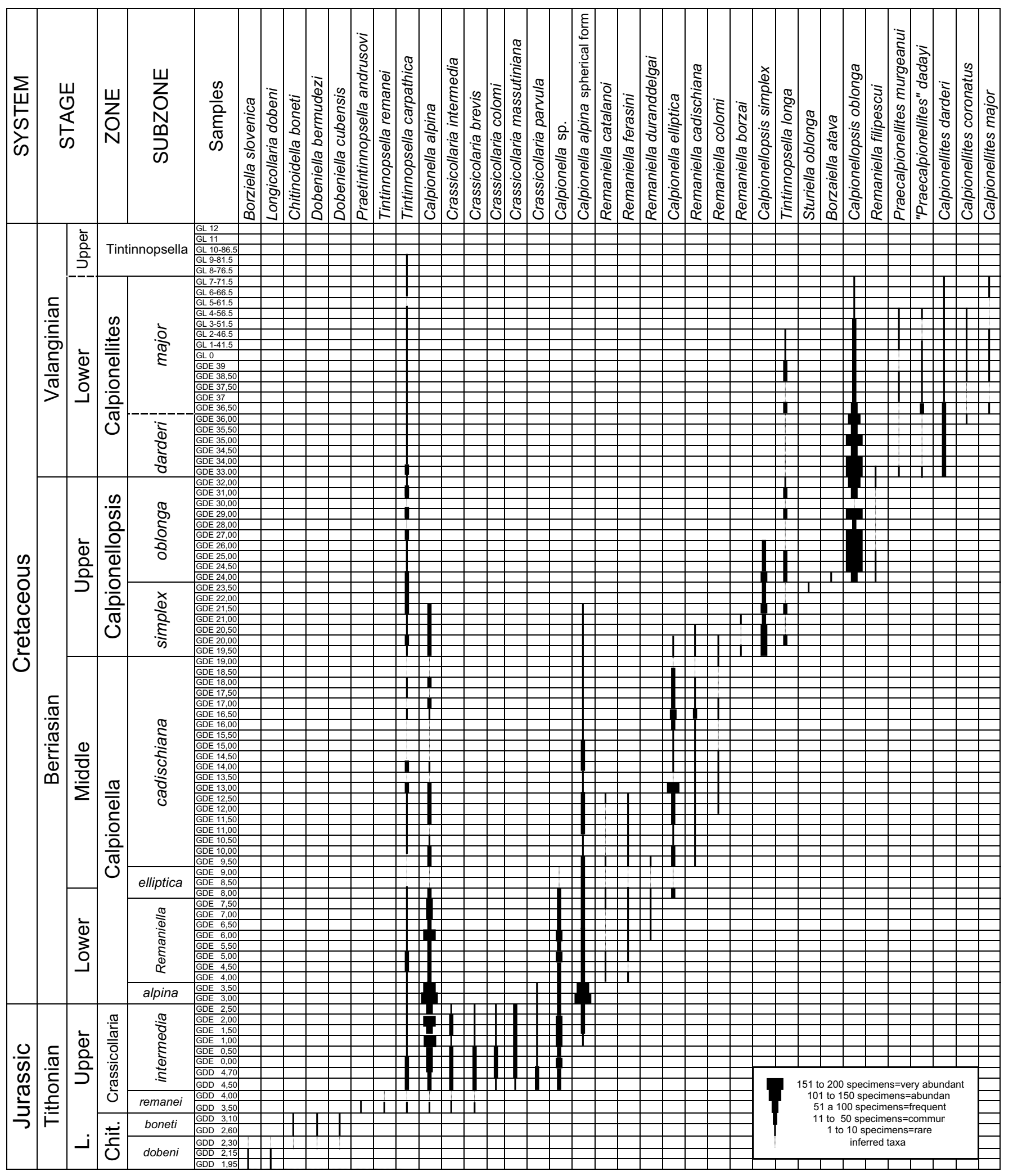

Fig. 4. Range chart of the calpionellid species recorded in the Guidaloca section. The thin sections were studied counting all the specimens in at least 100 visual fields (magnification of x100), to obtain statistical significance. 


\section{Assemblage VIII}

The first occurence of Remaniella cadischiana (COLOM) (Pl. II: figs. $7 ; 8 \mathrm{a}, \mathrm{b}$ ) defines the base of this assemblage. The assemblage is also dominated by $C$. elliptica CADISH, meanwhile $C$. alpina LORENZ is also present with large variety, including spherical forms, but decreasing upward; rare $T$. carpathica (MurgeAnu \& Filipescu) can be found. The genus Remaniel$l a$ is scarcely represented, although well diversified toward the lower part of the assemblage, with $R$. duranddelgai PoP, $R$. catalanoi PoP, $R$. ferasini (CATALANO). In the upper part of the assemblage, only $R$. cadischiana (COLOM) and $R$. colomi (Pl. II: figs. 9a, b) persisted.

\section{Assemblage IX}

This assemblage is tipically characterized by a low abundance of calpionellids, dominated by Calpionellopsis simplex (ColOM) (Pl. II: figs. 10, 11). The genus Tintinnopsella is represented by $T$. longa (COLOM) (Pl. III: fig. 3) and T. carpathica (Murgeanu \& Filipescu). Remaniella cadischiana (COlOM) and $R$. colomi PoP are scarce and present only in the lower part of the assemblage, as well as $C$. elliptica $\mathrm{CADISCH}$ and $C$. alpina LORENZ (large variety, including spherical forms). Toward the top of the assemblage, Sturiella oblonga BorZA (Pl. II: figs. $18 \mathrm{a}, \mathrm{b}$ ) is recorded.

\section{Assemblage $X$}

It is dominated by Calpionellopsis oblonga (CADISH) (Pl. II: figs. 12, 13) (reaching up to $90 \%$ ), together with common Cs. simplex (COLOM), T. longa (COLOM), T. carpathica (MurgeAnu \& FILIPESCU), and rare Remaniella filipescui (POP) (Pl. II: figs. 20; 22a, b) and Borzaiella atava GRÜN \& BLAU (Pl. II: figs. 23a, b).

\section{Assemblage XI}

This assemblage is charaterized by the appearance of Calpionellites darderi (COLOM) (Pl. III: fig. 5) and is dominated by Cs. oblonga (CADISCH), and subordinately Cs. coronatus (TREJO) (Pl. III: figs. 4a, b), "Praecalpionellites" dadayi (KNAUER) (Pl. II: figs. 21a, b) and Praecalpionellites murgeanui (POP) (Pl. II: figs. 17a, b; Pl. III: figs. 1a, b; 6). Tintinnopsella longa (COLOM) and $R$. filipescui Pop are very rare.

\section{Assemblage XII}

This assemblage is similar to assemblage XI, except for the record of Calpionellites major (COLOM) (Pl. II: fig. 16; Pl. III: figs. 2a, b) and the progressive decreasing of Cs. oblonga (CADISCH) toward the upper part, which determines an impoverishment in calpionellids.

\section{Assemblage XIII}

The younger assemblage recognized in the studied sections in Western Sicily is composed only by rare Tintinnopsella gr. carpathica (MURGEANU \& FiliPESCU), after the Last Occurrence (LO) of Calpionellites and Praecalpionellites.

\section{Biostratigraphy and chronostratigraphy}

These successive assemblages provide the first calpionellid biochronostratigrafic framework for Western Sicily, which can be correlated with the previous works for other Perimediterranean areas (Remane 1971; Olóriz et al. 1995; Pop 1994b; Grün \& Blau 1997; Reháková \& Michalík 1997) (Fig. 5).

A detailed quantitative calpionellid analysis in sections belonging to the Trapanese and Saccense Domains allowed us to propose a high-resolution bio-chronostratigraphic scheme for the Upper Tithonian-Hauterivian interval of Western Sicily successions.

The assemblage I defines the lower part of the Chitinoidella Zone, Dobeni Subzone, according to Pop (1997), Reháková \& Michalík (1997) and Reháková (2002), who recently revisited these chitinous forms.

The genera and species (not reported previously from Sicily) which define the assemblage II are distributed in the upper part of the Chitinoidella Zone, Boneti Subzone, according to Pop (1997), Reháková \& Michalík (1997) and Reháková (2002) .

The lower boundary of the assemblage III coincides with the first occurence of Calpionellidae BONET (hyaline Calpionellids), the upper boundary (the base of assemblage IV) is marked by the record of large specimens of $C$. alpina LoRENZ.

This assemblage III fits well with the Remanei Subzone of the Crassicollaria Zone, characterized from Remane et al. (1986) to Grün \& Blau (1997) by the presence of primitive forms of Crassicolaria, together with Tintinnopsella and small sized Calpionella.

The first occurence of $C$. alpina large variety marks the base of the assemblage IV. This main event defines the base of the Intermedia Subzone (Crassicollaria Zone). According to Olóriz et al. (1995) and Remane et al. (1986), the maximum diversification of the genus Crassicollaria occurred in the Intermedia Subzone. Pop (1994b, 1996) and Reháková \& Michalík (1997) divided the middle-upper part of the Crassicollaria Zone into two subzones, although using different criteria; Pop (1994b, 1996) defined the Intermedia Subzone on the base of the FO of C. alpina LorEnz (large form) and the Colomi Subzone upwardly, while Reháková \& Michalík (1997) called the intermediate interval of the Crassicollaria Zone as Brevis Subzone (for the first occurence of $\mathrm{Cr}$. brevis REMANE), before the FO of Cr. colomi DoBEN which defines the upper Colomi Subzone (Fig. 5).

Remane (1963, 1964, 1971) and Le Hégarat \& Remane (1968) recognized the A2 and A3 Subzones in the Vocontian Trough; the base of A2 Subzone is marked by the predomi- 
nance of $C r$. intermedia (DURAND-DELGA) on Cr. brevis REMANE, while the base of A3 is marked by the predominance of Cr. brevis REMANE over Cr. intermedia (DuRAND-DELGA). Unfortunately, due to the constant abundance of Crassicollaria species in this interval, it is not possible to apply quantitative abundance as a parameter to refine the biostratigraphy at the Subzone level, as proposed by Pop (1996) and Reháková \& Michalík (1997). Moreover, the record of $R$. catalanoi, which appears lately, does not permit to define a subzone in the upper part of the Crassicollaria Zone, based on the genus Remaniella according to Grün \& Blau (1997).

According to the record of the well-known "explosion" in the Mediterranean region of $C$. alpina LORENZ (small and spherical forms), the assemblage $\mathrm{V}$ is referred to the Calpionella Zone, Alpina Subzone. Thus, the base of this subzone is equivalent to that of the Alpina Subzone in Reháková \& Michalík (1997), Pop (1994b, 1996) and Olóriz et al. (1995). This assemblage has been also recorded in the Umbria-Marche area, Central Italy (Micarelli et al. 1977; Hou_a et al. 2004). Similarly, in the Vocontian Trough, the base of the B Zone was defined by the "explosive" extension of a smaller and more spherical form of C. alpina LoRENZ (Remane 1963, 1971), which coincides with the Jurassic/Cretaceous boundary.

The base of assemblage VI is defined by the first occurence of calpionellids with composite collars, which allows to identify the Remaniella Subzone of the Calpionella Zone.

This assemblage is referred to the Remaniella Subzone (Olóriz et al. 1995) or the Ferasini Subzone by Reháková \& Michalík (1997) and Pop (1994b, 1996). Grün \& Blau (1997) registered the older specimens of Remaniella in the Ra Stua area (Italy) within the Crassicollaria Zone and used this record to define the Catalanoi Subzone in the upper part of this Zone. In the studied sections, the FO of the genus Remaniella is already found in the Berriasian, after the explosion of $C$. alpina LORENZ.

The studied assemblage VII with abundant $C$. elliptica CADISCH and diverse Remaniella is therefore referred to the Elliptica Subzone of the Calpionella Zone. As traditionally noted from Catalano \& Liguori (1971) to Reháková \& Michalík (1997), the FO of C. elliptica CADISCH defines the Elliptica Subzone.

In the assemblage VIII, according to Grün \& Blau (1997) for the Ra Stua area, the FO of $R$. cadischiana (COLOM) defines also the base of the Cadischiana Subzone in the upper part of the Calpionella Zone. Pop (1994b, 1996) defined the Longa Subzone, in the upper part of the Calpionella Zone, on the basis of the FO of $T$. longa (COLOM), which occurs upwards, together with Cs. simplex (COLOM) in Western Sicily.

For the Vocontian Trough, Remane (1971) defined the C Zone in the upper part of the Calpionella Zone (Remane et al. 1986), on the basis the predominance of large forms of T. carpathica (MURGEANU \& FiliPESCU). Toward the middle part of the assemblage VIII recorded in Western Sicily, there is also an occurence of large forms of $T$. carpathica (MURGEANU \& FILIPESCU) in significant percentage (40\%), but only punctual- ly reached in one level. Thus, we do not agree with the use of this bioevent to define the base of C Zone as in the Vocontian Through (Remane 1971). The studied sections in Western Sicily revealed a heterochrony within two events, which have been traditionally considered isochronous: the FO of $R$. cadischiana (COLOM) (base of Cadischiana Subzone; Grün \& Blau 1997) and the increase of $T$. carpathica (MURGEANU \& FiliPESCU) with mostly large forms (base of the C Zone in Remane 1971).

Similarly to other Tethyan palaeomargins (Pop 1994b, 1996; Grün \& Blau 1997; Reháková and Michalík 1997), the FO of Cs. simplex (COLOM) without Cs. oblonga (CADISCH) in the assemblage IX, permits to identify the Simplex Subzone of the Calpionellopsis Zone.

The FO of Cs. oblonga marks the base of the assemblage $\mathrm{X}$, that is attributed to the Oblonga Subzone of the Calpionellopsis Zone. According to Grün \& Blau (1997), after the FO Cs. oblonga (CADISCH), which coincides with the FO of $R$. filipescui (POP), Cs. simplex (COLOM) is rapidly counterbalanced by Cs. oblonga (CADISCH). Similarly to the record in Ra Stua (Italy) (Grün \& Blau 1997), the studied sections show that the FO of Cs. oblonga (CADISCH) occurs together with the first record of $R$. filipescui (PoP).

In the assemblage XI, as traditionally noted in many other Tethyan palaeomargins (Betic, Appennines, Alps, Carpathes), the FO of $C t$. darderi (COLOM) permits to identify the Darderi Subzone within the Calpionellites Zone. The base of Calpionellites Zone coincides with the Berriasian/Valanginian boundary, according to Aguado et al. 2000.

The base of the assemblage XII is marked by the occurrence of Ct. major (COLOM), that characterizes the Major Subzone within the upper part of the Calpionellites Zone, according to Pop (1994b, 1996), Grün \& Blau (1997), Reháková \& Michalík (1997).

The Assemblage XIII corresponds to the Tintinnopsella Zone. The exclusive presence of $T$. gr. carpathica (COLOM) fits well with the typical record for the uppermost part of the calpionellid-bearing interval, already in the Hauterivian (Pop 1994b, Rehákova \& Michalík 1997).

\section{Conclusions}

A detailed calpionellid study on sections belonging to Western Sicily allowed us to propose a bio-chronostratigraphic scheme for the Tithonian-Valanginian interval in the region.The calpionellid abundance is maintaned, although variable in detail, but the diversity decreases toward the upper part of the Calpionella Zone, with the only record of the Tintinnopsella, Calpionella and Remaniella genera. The interval with the greatest richness of calpionellids (95\% of the microbiofacies) is the Oblonga Subzone (Calpionellopsis Zone), after which the abundance and diversity decrease in the Calpionellites, and even more in the Tintinnopsella Zone.

Eight genera are reported for the first time in Western Sicily: Chitinoidella, Dobeniella, Borziella, Longicollaria, Praetintinnopsella, Praecalpionellites, Sturiella and Borzaiella (see 


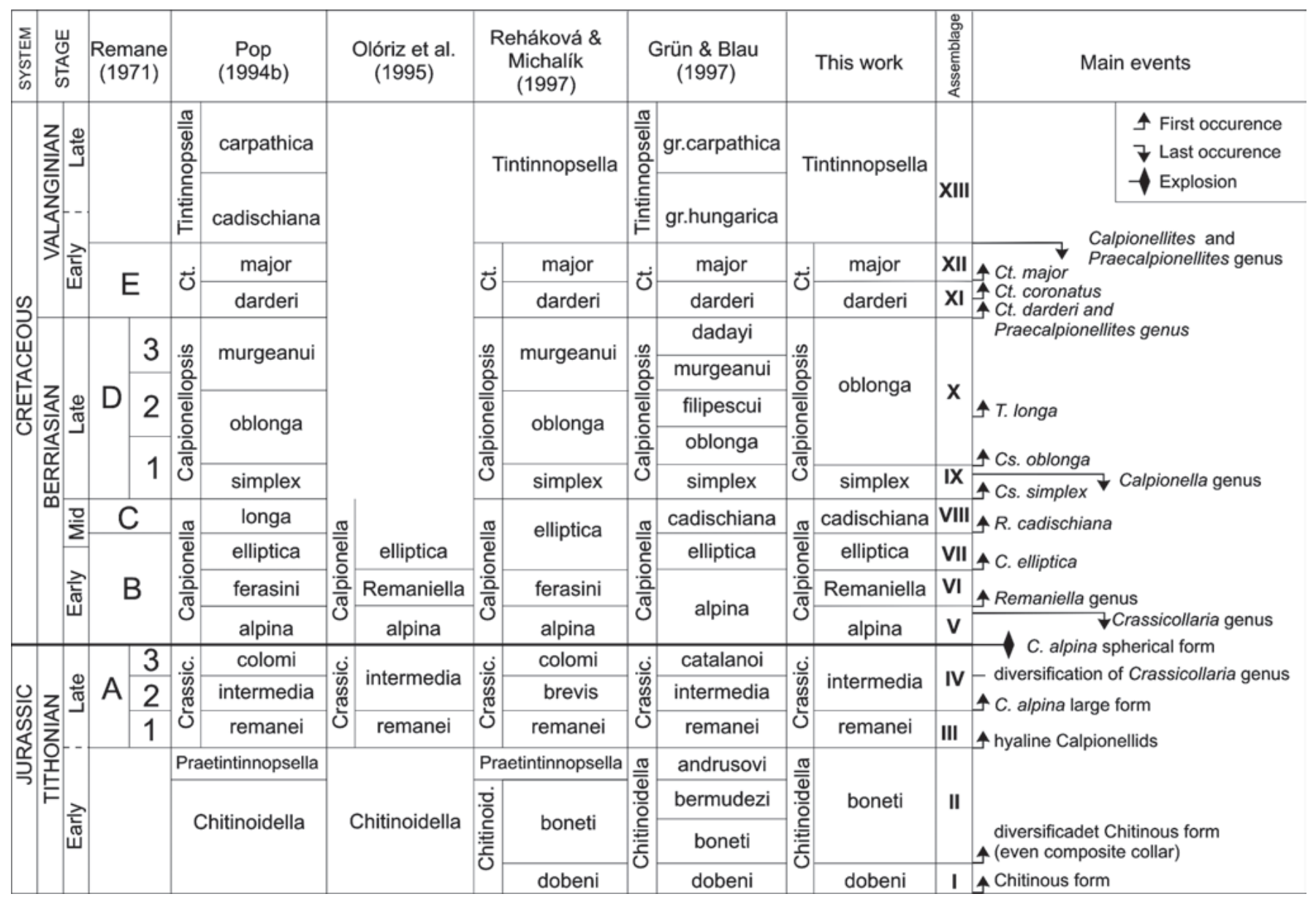

Fig. 5. Comparative chart of the proposed calpionellid zonation for Western Sicily with the previous works of Remane (1971), Pop (1994b), Olóriz et al. (1995), Grün \& Blau (1997) and Reháková \& Michalík (1997).

Appendix 1). According to Pop (1997) and Reháková (2002), the record of diverse chitinous-test calpionellids (Chitinoidella, Dobeniella, Borziella and Longicollaria) permitted to precise the Dobeni and Boneti Subzone of the Chitinoidella Zone. The record of the cryptic genus Praetintinnopsella (doublewalled forms), together with hyaline calpionellids of the Remanei Subzone (Crassicollaria Zone), prevent the differentiation of the Bermudezi and Andrusovi Subzone, as proposed by Pop 1996, Grün \& Blau 1997 and Reháková \& Michalik 1997.

The calpionellid assemblages of Crassicollaria Zone allow to recognize two Subzones: Remanei and Intermedia. The FO of hyaline calpionellids characterizes the base of the Remanei Subzone, while the predominance of diverse Crassicollaria marks the base of the Intermedia Subzone.

According to many previous proposals, we accepted that the Tithonian/Berriasian boundary is defined by the sudden "explosion" of $C$. alpina LORENZ spherical forms (Remane 1986), marking the base of the Calpionella Zone. This Zone can be well subvidided in four Subzones (Alpina, Remaniella, Elliptica and Cadischiana) in Western Sicily, as in Pop's proposal (1996) for the Western Carpathes.

The upper part of the Calpionellopsis Zone in the Guidaloca section is slightly tectonized and this could explain why the Murgeanui and Dadayi Subzone (in Pop 1994b; Reháková \& Michalík 1997) or the Filipescui, Murgeanui and Dadayi Subzone (in Grün \& Blau 1997) have not been recognized. In Western Sicily, the markers Pct. murgeanui (POP) and "Pct." dadayi (KNAUER) have their FO synchronous with $C t$. darderi (COLOM).

An atypical record in Western Sicily is the LO of Cs. oblonga, which has been recorded up to the top of the Calpionellites Zone, whereas Remane (1998) refers it to the base of the Calpionellites Zone. The LO of Cs. oblonga is highly variable from Pop (1994b) and Reháková \& Michalík (1997), who placed it within the Calpionellites Zone and Grün \& Blau (1997) who extended it until the lower part of Tintinnopsella Zone. 
The Subzone definition of the Tintinnopsella Zone is difficult because of the low abundance of calpionellids in the upper part of the studied sections. Thus, the Late Valanginian, as well as the Valanginian/Hauterivian boundary, cannot be defined. The calpionellid disappearance in the upper part of the sections prompted an Hauterivian age, as commonly accepted by Remane et al. (1986). The Lorenziella genus is not present in the studied sections, although this rare genus was recorded in the Inici Mount (Trapanese Domain) by Cecca et al. (2001).

Thirteen successive calpionellid assemblages characterize the record in Western Sicily for the uppermost Lower Tithonian-Hauterivian. The registered calpionellid bioevents lead to recognize a bio-chronostratigraphic scheme at the Zone/Subzone level, correlable on a long-distance, and based with the previous works of Remane (1971), Olóriz et al. (1995), Pop (1994b), Grün \& Blau (1997), and Reháková \& Michalík (1997) for the Western Tethys.

\section{Acknowledgements}

We are grateful to D. Reháková and an anonymous referee for comments and suggestions. Financial aid was provided by Research Project GV04B-629 (Generalitat Valenciana) and the Italian MURST, granted to G. Parisi, COFIN 1999 and 2001. This paper is dedicated to the memory of Prof. Jürgen Remane.

\section{REFERENCES}

Aguado, R., Company, M. \& Tavera, J.M. 2000: Berriasian/Valanginian boundary in the Mediterranean region: new data from the Caravaca and Cehegín sections, SE Spain. Cretaceous Research 21, 1-21.

Allemann, F., Catalano, R., Fares, F. \& Remane, J. 1971: Standard Calpionellid Zonation (Upper Tithonian-Valanginian) of the Western Mediterranean Province. In: Farinacci, A. (Ed.): Proceedings of the II Planktonic Conference, Roma 1970, 1337-1340.

Altiner, D. \& Ozkan, S. 1991: Calpionellid zonation in North-Western Anatolia (Turkey) and calibration of the stratigraphic ranges of some benthic foraminifera at the Jurassic/Cretaceous boundary. Geologica Romana 27, 215-235.

Andrusov, D. 1950: Mesozoic fossils of the Carpathian. Plants and protozoans. štat geologickeho ùstavu 25, $165 \mathrm{pp}$.

Bonet, F. 1956: Zonificación microfaunística de las calizas cretácicas del Este de México. Boletín de la Asociación Mexicana de Geólogos Petroleros 8, 389-488.

Borza, K. 1966: Neue Arten der Gattung Chitinoidella Doben, 1962 in den Westkarpaten. Geologický Sborník Slovenskej Akademie Vied 17, 259-265.

Borza, K. 1969: Die Mikrofacies und Mikrofossilien des Oberjuras und der Unterkreide der Klippenzone der Westcarpaten. Slovak Academy of Sciences Publishing House, Bratislava 302, 299 pp.

Borza, K. 1981: Sturiella nov.gen. (Calpionellidae Bonet, 1956) aus der unteren Kreide der Westkarpaten. Západné Karpaty, sér. Paleontológia 6, 93-97.

Caracuel, J.E., Parisi, G., Bartolini, A., Mattioli, E. \& Andreini, G. 2002: Integrated biostratigraphy in the Rosso Ammonitico facies of the Guidaloca Section (Upper Jurassic/Cretaceous Boundary). In: Santantonio, M. (Ed.): General field trip guidebook, 6th International Symposium on the Jurassic System, Palermo 2002, 49-58.

Catalano, R. 1965: Calpionelle di Calabianca (Castellammare, Sicilia). Atti della Società Toscana Scienze Naturali 72, 485-507.

Catalano, R. \& Liguori, V. 1971: Facies a Calpionelle della Sicilia Occidentale. In: Farinacci, A (Ed.): Proceedings of the II Planktonic Conference, Roma 1970, 167-209.
Catalano, R. \& Lima, N. 1964: Distribuzione di alcune Calpionelle nel Malm e nel Neocomiano di Castellammare del Golfo. Rivista Mineraria Siciliana 14, 1-9.

Cecca, F., Savary, B., Bartolini, A., Remane, J. \& Cordey, F. 2001: The Middle Jurassic-Lower Cretaceous Rosso Ammonitico succession of Monte Inici (Trapanese domain, western Sicily): sedimentology, biostratigraphy and isotope stratigraphy. Bulletin de la Societé géologique de France 172, 647-660.

Chiari, M., Baldanza, A. \& Parisi, G. 2004: Integrated stratigraphy radiolarians and calcareuos nannofossils) of the Jurassic Siliceous sediments from Monte Kumeta (Western Sicily, Iatly). Rivista Italiana di Paleontologia e Stratigrafia 110, 129-140.

Colom, G. 1948: Fossil tintinnids: loricated Infusoria of the order of the Oligotricha. Journal of Paleontology 22, 233-263.

Deflandre, G. 1936: Tintinnoïdiens et Calpionelles. Comparaison entre les Tintinnoïdiens, Infusoires loriqués pélagiques des mers actuelles et les Calpionelles, microfossiles de l'époque secondaire. Bulletin de la Societé géologique de France 22, 112-122.

Doben, K. 1963: Über Calpionelliden an der Jura/Kreide-Grenze. Mitt. Bayer. Staatssamml. Paläontologie und historie Geologie 3, 35-50.

Furrazola-Bermúdez, G. 1965: New species of tintinnids from Upper Jurassic of Cuba. Instituto Cubano de Recursos Minerales. Publication Especial 2, $1-29$.

Grün, B. \& Blau, J. 1996: Phylogenie, systematik und biostratigraphie der Calpionellidae Bonet, 1956: neue daten aus dem Rosso Ammonitico Superiore und dem Biancone (Oberjura/Unterkreide: Tithon-Valangin) von Ra Stua (Prov. Belluno, Italien). Revue de Paléobiologie 15, 571-595.

Grün, B. \& Blau J. 1997: New aspects of calpionellid biochronology: proposal for a revised calpionellid zonal and subzonal division. Revue de Paléobiologie 16, 197-214.

Grün, B. \& Blau J. 1999: On Praecalpionellites PoP (Capionellidae BonET) and description of Praecalpionellites hillebrandti n. sp. (Lower Cretaceous, Italy). Neues Jahrbuch Für Geologie und Paläontologie Abhandlungen 211, 201-212.

Houša, V., Krs, M., Man, O., Pruner, P., Venhodová, D., Cecca, F., Nardi, G. \& Piscitello, M. 2004: Combined magnetostratigraphic, palaeomagnetic and calpionellid investigations across Jurassic/Cretaceous boundary strata in the Bosso Valley, Umbria, central Italy. Cretaceous Research 25, 771-785.

Knauer, J. 1963: Calpionellidea-rendszertani kérdések. (Problèmes systématiques des Calpionellidés). A Magyar Állami Földtani Intézet Évi Jelentése 2, 155-168.

Le Hégarat, G. \& Remane, J. 1968: Tithonique supérieur et Berriasien de l'Ardèche et de l'Herault. Corrélation des Ammonites et des Calpionelles. Géobios 1, 7-70.

Marino, M.C., Andreini, G., Baldanza, A., D’Arpa, C., Mariotti, N., Pallini, G., Parisi, G. \& Petti, F.M. 2004: Middle Jurassic/Early Cretaceous integrated biostratigraphy (ammonites, calcareous nannofossils and calpionellids) of the Contrada Diesi section (South-Western Sicily, Italy). Rivista Italiana di Paleontologia e Stratigrafia 110, 357-372.

Micarelli, A., Potetti, M. \& Chiocchini, M. 1977: Ricerche microbiostratigrafiche sulla Maiolica della Regione Umbro-Marchigiana. Studi Geologici Camerti 3, 57-86.

Olóriz, F., Caracuel, J.E., Marques, B. \&. Rodríguez-Tovar, F.J. 1995: Asociaciones de Tintinnoides en facies Ammonitico Rosso de la Sierra Norte (Mallorca). Revista Española de Paleontología, $N^{\circ}$ Homenaje al Dr. G. Colom, 77-93.

Pokorny, V. 1954: Principles of zoological micropaleontology. Naklad Cs. Akademie Ved, Praha, 651 pp.

Pop, G. 1974: Une nouvelle espéce néocomienne de Calpionellidés. Révue roumanie de Géologie, Géophysique, Géographie 18, 105-107.

Pop, G. 1986: Réflexions sur certaines calpionelles néocomiennes. Studii Institute de Geologie, Geofiziă 70, 103-108.

Pop, G. 1994a: Systematic revision and biochronology of some BerriasianValanginian Calpionellids (Genus Remaniella). Geologica Carpathica 45, 323-331. 
Pop, G. 1994b: Calpionellid evolutive events and their use in biostratigraphy. Romanian Journal of Stratigraphy 76, 7-24.

Pop, G. 1996: Trois nouvelles espéces du genre Remaniella (Calpionellidae Bonet, 1956). Comptes Rendus de l'Académie des Sciences Paris 332, 317-323.

Pop, G. 1997: Révision systématique des chitinoïdelles tithoniennes des Carpathes méridionales. Comptes Rendus de l'Académie des Sciences Paris 324, série IIa, 931-938.

Reháková, D. 1998: Calpionellid genus Remaniella Catalano 1956 in Lower Cretaceous pelagic deposits of Western Carpathians. Mineralia Slovaca $30,443-452$.

Reháková, D. 2002: Chitinoidella Trejo, 1975 in Middle Tithonian carbonate pelagic sequences of the West Carpathian Tethyan Area. Geologica Carpathica 53, 369-379.

Reháková, D. \& Michalík, J. 1997: Evolution and distribution of calpionellidsthe most characteristic constituents of Lower Cretaceous Tethyan microplankton. Cretaceous Research 18, 493-504.

Remane, J. 1963: Les Calpionelles dans les couches de passage JurassiqueCrétacé de la fosse vocontienne. Travaux du Laboratoire de Géologie de la Faculté des Sciences de la Université de Grenoble 39, 25-82.

Remane, J. 1964: Untersuchungen zur Systematik und stratigraphie der Calpionellen in den Jura-Kreide-Grenzschichten des Vocontischen Troges. Palaeontographica 123, 1-57.

Remane, J. 1971: Les Calpionelles protozoaires planctoniques des mer mesogennes de l'epoque secondaire. Annales Guebhard Neuchatel 47, 370-393.

Remane, J. 1985: Calpionellids. In: Bolli, H.M. et al. (Ed s.) : Plankton Stratigraphy. Cambridge University Press, London, 555-572.

Remane, J. 1986: Calpionellids and the Jurassic-Cretaceous boundary. Acta Geologica Hungarica 29, 15-26.
Remane, J. 1998: Les calpionelles: possibilités biostratigraphiques et limitations paléobiogéographiques. Bulletin de la Societé géologique de France 169, 829-839.

Remane, J., Bakalova-Ivanova, D., Borza, K., Knauer, J., Nagy, I., Pop, G. \& Tardi-Filacz, E. 1986: Agreement of the subdivision of the standard Calpionellid Zones defined at the II Planktonic Conference, Roma 1970. Acta Geologica Hungarica 29, 5-14.

Ronchi, P., Lottaroli, F. \& Ricchiuto, T. 2000: Sedimentary and diagenetic aspects of the Liassic Inici Fm. and its stratigraphic context (Sicily Channel, Italy). Memorie della Società Geologica Italiana 55, 261-269.

Schmidt di Frieberg, P. 1965: Litostratigrafia petrolifera della Sicilia. Rivista Mineralogica Siciliana 88, 198-217.

Stefano, P. di 2002: An outline of the Jurassic stratigraphy and paleogeography of Western Sicily. In: 6th International Symposium on the Jurassic System, General Field Trip Guidebook, Palermo 2002, 21-27.

Stefano, P. di \& Mindszenty, A. 2000: Fe-Mn encrusted "kamenitza" and associated features in the Jurassic of Monte Kumeta (Sicily). Subaerial and/or submarine dissolution? Sedimentary Geology 132, 37-68.

Stefano, P. di, Mallarino, G., Marino, M., Mariotti, N., Muraro, C., Nicosia, U., Pallini, G. \& Santantonio M. 2002: New stratigraphic data from the Jurassic of Contrada Monzealese (Saccense domain, SW Sicily). Bollettino Società Geologica Italiana 121, 121-137.

Trejo, M. 1980: Distribucion estratigrafica de los Tintinidos Mesozoicos Mexicanos. Revista Instituto Mexicano Petròleo 12, 4-13.

Manuscript received March 9, 2006

Manuscript accepted June 25, 2007

Editorial handling: M. Chiari (Guest) \& J.-P. Billon-Bruyat 


\section{Appendix 1: Calpionellid taxonomy}

This appendix is focused on the taxonomical description of some genera of chitinous (Borziella, Longicollaria, Chitinoidella and Dobeniella) and hyaline calpionellids (Remaniella, Sturiella, Borzaiella and Praecalpionellites), recorded for the first time in the succession of Western Sicily.

\section{Family Chitinoidinellidae TREJO 1975}

As usually elsewhere, the record of chitinous calpionellids in Western Sicily is retricted to the upper part of the Lower Tithonian. Although they are quite scarce, very small, bad-preserved, and then, difficult to identify, it was possible to recognize specimens of the genus Borziella, Longicollaria and Dobeniella, recently defined by Pop (1997), along with the emended genus Chitinoidella DoBEN.

\section{Genus Borziella PoP 1997}

Ovoidal to spheroidal lorica with a rounded aboral pole and a small constriction in the preoral part. This is followed by a relatively short and outwardly deflected collar (Pop 1997).

\section{Borziella slovenica (BoRZA 1969)}

(Pl. I: figs. 1a, b)

1969 Chitinoidella slovenica n. sp. - Borza: 76-77, pl. 66, figs. 8, 9.

1997 Borziella slovenica (BoRZA) - Pop: 935, pl. 2, figs. 14, 15.

2002 Borziella slovenica (BoRZA) - Reháková: 371, pl. 2, figs. 9, 12.

Ovoidal to spheroidal lorica with a rounded aboral pole. The lorica is $40-48 \mathrm{~mm}$ in length, and $28-32 \mu \mathrm{m}$ in width. Its preoral part bears a small constriction followed by a relatively short outwardly deflected collar, similar to that of Tintinnopsella remanei BORZA or Lorenziella hungarica KNAUER (Reháková 2002). In Western Sicily, the common dimensions are 40-54 $\mu \mathrm{m}$ in length and $40-43 \mu \mathrm{m}$ in width. The species appears rarely in the Dobeni Subzone.

\section{Genus Longicollaria PoP 1997}

Elongated ovoidal lorica, with a conical aboral pole ended by a caudal appendage and a slight constriction in the preoral segment. The lorica, still showing a large opening, is continued by an elongated cylindrical or subcylindrical collar with progressively thicker walls towards the distal end. Generally, the collar length is comparable to that of the lorica (Pop 1997).

\section{Longicollaria dobeni (BoRZA 1966)}

(Pl. I: figs. 2a, b)

1966 Chitinoidella dobeni n. sp. - Borza: 259-261, pl. IX, figs. 1, 2.

1997 Longicollaria dobeni (BorZA) - Pop: 935, pl. 2, figs. 12, 13.

2002 Longicollaria dobeni (BORZA) - Reháková: 371, pl. 4, figs. 4-6.
Cup-shaped or ovoidal lorica with a conical aboral pole ended by a caudal appendage. The preoral segment of the lorica has a slight constriction followed by an elongated cylindrical or subcilyndrical collar, with a progressive thickening of the wall towards the distal end. The lorica is $48-65 \mu \mathrm{m}$ in length, and $34-42 \mu \mathrm{m}$ in width. Our specimens range from $40-54 \mu \mathrm{m}$ in length and $40-43 \mu \mathrm{m}$ in width. The FO of this species is at the base of Dobeni Subzone.

\section{Genus Chitinoidella DoBEN 1963}

Variably bell-shaped (ovoid to subcylindrical or cylindrical) lorica with an aboral pole ended by a caudal appendage and a large oral opening surrounded by a collar, constituting a more or less outwardly deflected lorica (Pop 1997).

\section{Chitinoidella boneti DoBEn 1963}

(Pl. I: figs. 3a, b; 4a, b; 5a, b)

1963 Chitinoidella boneti n. sp. - Doben: 42-44, pl. 6, figs. 1-5.

2002 Chitinoidella boneti DoBEN - Reháková: 371, pl. 2, figs. 1-4.

Microgranular calcitic, bell-shaped lorica, with a slight preoral constriction and a length / width ratio smaller than 1.5. Commonly, dimensions are $55-83 \mu \mathrm{m}$ in length and $40-50 \mu \mathrm{m}$ in width. The Western Sicily specimens recorded in the studied sections have a lorica length of 50-66 $\mu \mathrm{m}$ and width of 36-48 $\mu \mathrm{m}$. This rare species is restricted to the Boneti Subzone.

\section{Genus Dobeniella Pop 1997}

Elongated bell-shaped or cylindrical lorica, sometimes having a preoral constriction, with a caudal appendage and a large oral opening surrounded by a composite collar. The collar consists of two circumoral parts: the outer is outwardly deflected, the inner one is detached and ring-like with different cross-sections.

Dobeniella bermudezi (FurRAZOLA-BERMúdEZ 1965)

(Pl. I: Figs. 6a, b; 7a, b)

1965 Tintinnopsella bermudezi n. sp. - Furrazola-Bermúdez: 17-20, 28, pl. 1 , figs. 2a-c; pl. 2, figs. 6-8; pl. 3, fig.1; pl. 5, fig. 2.

1966 Chitinoidella bermudezi (FurRAzOLA-BERMúDEZ) - Borza: pl. 10, fig. 11.

2002 Dobeniella bermudezi (FurRazola-BermúdeZ) - Reháková: 371, pl. 3 , figs. 7-9.

Bell-shaped, elongated to subcylindrical lorica with an aboral pole ended by a caudal appendage and a large oral opening surrounded by a composite collar in which the elongated inner ring has a comma- or lens-like form (Pop 1997). The recorded specimens have a lorica length of $61-65 \mu \mathrm{m}$ and width of $40-45$ $\mu \mathrm{m}$. The species is rarely registered in the Boneti Subzone. 
Dobeniella cubensis (FURRAZOLA-BERMÚdEZ 1965)

(Pl. I: figs. 8a, b)

1965 Tintinnopsella cubensis n. sp. - Furrazola-Bermúdez: 13-16, 27, 28, pl. 1, fig. 1a-c; pl. 2, figs. $1-5$; pl. 5 , fig. 1.

1966 Chitinoidella cubensis (FurRAZOLA-BERMÚDEZ) - Borza: pl. 10, fig. 10.

1997 Dobienella bermudezi (Furrazola-Bermúdez) - Pop: 935, pl. 2, figs. 5,6 .

Bell-shaped elongated lorica with composite collar, in which an inner ring-like structure, almost rounded in cross-section, is developed. Our recorded specimens, always in the Boneti Subzone, range from $47-50 \mu \mathrm{m}$ in length to $36-40 \mu \mathrm{m}$ in width.

Family Calpionellidae BONET 1956

Genus Remaniella CATALANO 1965

Calpionellids with three diagnostic characters: 1) ovoid, bellshaped, cylindroid or cylindrical differently elongated loricas; 2) collar consisting of two circumoral, normally detached pieces (rings); c) aboral part ended with highly or slightly marked caudal appendage. According to Catalano (1965), the composite collar is the most important morphological feature of this genus. The two rings of the collar have a divergent and oblique position with respect to the oral end of the lorica. Particularly in transitional specimens to other calpionellids with composite collar, the oral end of the lorica may present an extremely small hollow located in the inner part, where the internal ring of the collar is jointed (articuled) (Pop 1994a). To characterize this genus, the morphology of both the collar and the lorica should be taken into account. In the studied sections, this genus appears in the Lower Berriasian, Remaniella Subzone (Calpionella Zone), with a maximum abundance and diversity in the Lower-Middle Berriasian (Cadischiana Subzone).

\section{Remaniella catalanoi PoP 1996}

(Pl. I: figs. 32a, b; Pl. II: figs. 4a, b)

1996 Remaniella catalanoi n. sp. - Pop: 320, figs. 10-15.

1998 Remaniella catalanoi PoP - Reháková: 446, pl. 1, figs. 3-5.

Bell-shaped to slightly ovoidal lorica with a conical aboral pole ended by a short caudal appendage. The lorica is about $80 \mathrm{~mm}$ in length and $60 \mathrm{~mm}$ in width. The collar consists of two unequal circumoral rings. The outer ring developes a lenticularshaped form, while the inner is filiform, marked by two simmetrical points in thin section. The identified specimens have a lorica length of $86-90 \mu \mathrm{m}$ and a width of 50-54 $\mu \mathrm{m}$. R. catalanoi Pop, appears at the base of the Remaniella Subzone, up to the last record in the Cadischiana Subzone.

Remaniella ferasini (CATALANO 1965)

(Pl. I: figs. 30a, b; 31a, b)

1965 Calpionellites ferasini n. sp. - Catalano: pl. II, figs. 1-5; pl. III, figs. 5-7.

1998 Remaniella ferasini (CATALANO) - Reháková: 446, pl. 1, figs. 1-2.
Small ovoidal lorica ended with a short caudal appendage or with acute aboral zone. Lorica dimensions (without aboral appendage) are approximately $65-80 \mu \mathrm{m}$ in length and $48-60 \mu \mathrm{m}$ in width, having the maximum width in its upper third. The collar consits of two detached circumoral rings with almost equal and triangular-shaped profiles in trasversal sections. The inner ring appears as an inward extension of the oral part of the lorica, whereas the outer ring is more or less divergent. In polarized light, the inner ring reveals extinction at $45^{\circ}$ if compared to the oral part of the lorica.

Common dimensions of our specimens are 60-74 $\mu \mathrm{m}$ in length and 40-55 $\mu \mathrm{m}$ in width. Remaniella ferasini (CATALANO) appears, as a rare component, from the base of Remaniella Subzone. The younger specimens were observed in the middle part of the Cadischiana Subzone.

\section{Remaniella duranddelgai Pop 1996}

(Pl. II: figs. 3a, b; 6a, b)

1996 Remaniella duranddelgai n. sp. - Pop: 320, pl. 2, figs. 1-6.

1998 Remaniella duranddelgai PoP - Reháková: 446, pl. 1, figs. 6-7.

Bell-shaped to slightly ovoid lorica with a conical aboral part ending with a short caudal appendage and a detached bipartite collar composed of two unequal circumoral rings. In cross-section, the inner ring is triangular-shaped in the direction of the oral part, sometimes slightly inwardly oriented, whereas the outer ring is more or less lenticular-shaped.

The identified specimens are $82-90 \mu \mathrm{m}$ in length and $46-53$ $\mu \mathrm{m}$ in width. The first appearence of this rare species occurred in the middle part of the Remaniella Subzone, and the last occurrence was observed in the lower part of the Cadischiana Subzone.

Remaniella colomi PoP 1996

(Pl. II: figs. 9a, b)

1996 Remaniella colomi n. sp. - Pop: 320, pl. 2, figs. 7-9.

1998 Remaniella colomi PoP - Reháková: 446, pl. 1, figs. 8-10.

Cylindrical lorica with a conical aboral part ending with a short caudal appendage and a detached bipartite collar consisting of two unequal circumoral rings. In cross-section, the inner ring is clearly triangular-shaped placed in continuity with the oral part, sometimes slightly inwardly directed; the outer ring is more developed and broadly-lenticular shaped.

The studied specimens are 86-90 $\mu \mathrm{m}$ in length and 61-65 $\mu \mathrm{m}$ in width, remarkably wider than Remaniella duranddelgai Pop. The species was recorded in the Simplex Subzone.

Remaniella borzai PoP 1994

(Pl. II: figs. 19a, b)

1994 Remaniella borzai n. sp. - Pop: 329, pl. 1, figs. 13-16.

1998 Remaniella borzai PoP - Reháková: 446, pl. 1, figs. 11-12. 
Cylindrical highly to slightly elongated lorica with aboral appendage. The loricas reach $90-110 \mathrm{~mm}$ in length and 60-70 $\mathrm{mm}$ in width. The oral part ends with a composite collar, with the outer ring broadly lenticular-elongated, sometimes slightly curved and obliquely placed, with respect to the lorica wall. The inner ring is filiform (punctiform in transverse section), showing extincion at $45^{\circ}$ from the lorica under polarized light.

The identified specimens have a lorica length of $81-118 \mu \mathrm{m}$ and width of $50-70 \mu \mathrm{m}$. This species is extremely rare and difficult to separate from Tintinnopsella carpathica due to the similarity of the lorica, although the $R$. borzai has clearly two rings. The species ranges from the upper part of the Cadischiana Subzone to the Simplex Subzone

Remaniella cadischiana (COLOM 1948)

(Pl. II: figs. 7; 8a, b)

1948 Tintinnopsella cadischiana n.sp. - Colom: 247, pl. 12, figs. 34-35.

1965 Remaniella cadischiana (COLOM) - Catalano: pl. I, figs. 6, 7, 11-14; pl. III, fig. 1.

1996 Remaniella cadischiana (COLOM) - Grün \& Blau: 591, pl. I, figs. 4-7.

Cylindrical or nearly cylindrical elongated lorica with acute aboral part, or more often with well-developed caudal appendage; they reach $90-150 \mathrm{~mm}$ in length and $60-80 \mathrm{~mm}$ in width. The collar consists of two circumoral detached rings, frequently oblique-divergent. Frequently, the outer ring is slightly curved and leans on the inner one. Generally, the inner ring is shorter than the outer, although they occasionally can be equal, forming a V-shaped collar. Rarely, in the inner oral end of the lorica a small hollow is preserved, where the internal ring is inserted.

Dimensions of our specimens are $98-112 \mu \mathrm{m}$ in length and $52-56 \mu \mathrm{m}$ in width. The species occurs from the base of the Cadischiana Subzone to the lower part of Simplex Subzone.

\section{Remaniella filipescui Pop 1994}

(Pl. II: figs. 20; 22a, b)

1994 Remaniella filipescui n.sp. - Pop: 329, pl. I, Figs. 7-12.

1996 Praecalpionellites filipescui (PoP) - Grün \& Blau: 593, pl. II, figs. 10.

1998 Remaniella filipescui PoP - Reháková: 446, pl. 1, figs. 13-15.

Cup- or bell-shaped lorica with an aboral appendage and a composite collar with two unequal divergent circumoral rings highly to slightly oblique with respect to the oral extremity. The maximum width is placed near the oral part. Commom dimensions are $75-95 \mu \mathrm{m}$ in length and $65-80 \mu \mathrm{m}$ in width (holotype $=90 \times 87 \mu \mathrm{m})$; length $/$ width ratio is below 1.5 (Pop 1994a).

In the studied sections, the species ranges from the upper part of Oblonga Subzone to the end of the Major Subzone, with dimensions of $84-98 \mu \mathrm{m}$ in length and $70-82 \mu \mathrm{m}$ in width.

\section{Genus Sturiella BorZA 1981}

Cylindrical hyaline lorica with funnel-shaped double collar, connected to the lorica. The inner collar is parallel to the lorica, while the outer one is longer (Borza 1981).

\section{Sturiella oblonga BORZA 1981}

(Pl. II: figs. 18a, b)

1981 Sturiella oblonga n.sp. - Borza: 97, pl. XXXV, figs. 1-9.

1996 Sturiella oblonga BorZA - Grün \& Blau: 593, pl. II, figs. 13.

1998 Sturiella oblonga BoRZA - Reháková: 446, pl. 1, figs. 18-19.

Cylindrical lorica with funnel-shaped double collar connected to the lorica walls. The inner collar, nearly parallel to the lorica, is smaller than the outer, which is highly divergent.

Our forms of this species, which is extremely rare elsewhere (in Western Sicily in particular) have a dimension of 155 $\mu \mathrm{m}$ in length and $76 \mu \mathrm{m}$ in width, slightly bigger than the specimens from Ra Stua (Italy) (Grün \& Blau 1996) and from Western Carpathians (Reháková 1998). Differently from Grün \& Blau (1996) (upper part of Oblonga Subzone) and Reháková (1998) (Early to Middle Berriasian), Sturiella oblonga BORZA in Western Sicily is restricted to the upper part of the Simplex Subzone.

\section{Genus Borzaiella GRÜN \& BLAU 1996}

Amphora-shaped lorica with a caudal appendage. The diagnostic feature is the comma-shaped collar, adjacent to the terminal part of the lorica (Grün \& Blau 1996).

\section{Borzaiella atava GRÜN \& BLAU 1996}

(Pl. II: figs. 23a, b)

1996 Borzaiella atava gen. n., n. sp. - Grün \& Blau: 593, pl. II, figs. 1, 2, 6.

Amphora-shaped lorica with a marked caudal appendage. The single comma-shaped collar is arranged with variable orientation at the end of the lorica, although the convex side is always adjacent to the terminal part of the lorica. Borzaiella atava GRÜN \& BLAU is an extremely rare species, previously recorded only in the Ra Stua section, Belluno Basin, Italy (Grün \& Blau 1996). The registered specimens in Western Sicily (mean values of $120 \times 80 \mu \mathrm{m})$ are slightly bigger than the holotype. This species is recorded only at the base of the Oblonga Subzone.

\section{Genus Praecalpionellites Pop 1986}

Parabolic or cylindric loricas with pointed aboral zone in longitudinal section. The tripartite collar is the most important character and it is diagnostic to separate this genus from others with composite collar (Remaniella, Calpionellites); it has two rings, inner and outer, with the extreme of the lorica outwards in between. The extreme of the lorica has a concave thinner part, in which the inner ring is situated. This inner ring is lenti- 
cular, similar to that of Calpionellites darderi (COLOM), and can be joined to the lorica or detached from it. The outer ring is also lenticular, divergent and highly to slightly curved upwards. Generally, the dimension of the lorica ranges from $50-130 \mu \mathrm{m}$ in length and 40-100 $\mu \mathrm{m}$ in width (Pop 1986).

\section{Praecalpionellites murgeanui (PoP 1974)}

(Pl. II: figs. 17a, b; Pl. III: figs. 1a, b; 6)

1974 Calpionellites murgeanui n. sp. - Pop: 105, pl. 1, figs. 1-5, 7-9.

1997 Praecalpionellites murgeanui (PoP) - Grün \& Blau: 211, pl. 2, fig. 4.

The axial section of the lorica is amphora-shaped with an acute caudal pole. The collar apparatus consists of two rings, developed? from below the oral end of the lorica. Well-preserved specimens show the lorica converging at the base of the inner collar ring. This particular collar structure, was called "tripartite" by Knauer (1963) and Pop (1974). Average dimensions for the specimens registered in Western Sicily are 108-122 $\mu \mathrm{m}$ in length and $72-83 \mu \mathrm{m}$ in width.

This species usually occurs in the upper part of the Oblonga Subzone (Grün \& Blau 1997; Reháková 1998) while in the studied sections it appears at the base of the Darderi Subzone and the last occurence was recorded in the upper part of the Major Subzone.
“Praecalpionellites” dadayi (KNAUER 1963)

(Pl. II: figs. 21a, b)

1963 Calpionellites dadayi n.sp. - Knauer: 157, pl. 1, figs. 4-5, 12-13.

1974 Remaniella dadayi (KNAUER) - Pop: pl. 4, figs. 16.

1997 Praecalpionellites dadayi (KNAUER) - Grün \& Blau: 211, pl. 2, fig. 5.

Cylindrical lorica that widens remarkably in correspondence of the oral opening, where the walls end with a moderate inflexion. Lorica height ranges from 145 to $165 \mu \mathrm{m}$ and width from 75 to $92 \mu \mathrm{m}$. Conversely to Praecalpionellites murgeanui (POP), the two rings of the collar apparatus are placed above the lorica end ("bipartite collar" in the terminology of Knauer 1963), and this makes the apparatus quite similar to those of Remaniella or Calpionellites. The convergence of inner ring and the divergence of the outer one separate the species from Calpionellites. Nevertheless, doubt remains about the inclusion of this species in the genus Remaniella, following Pop (1997) and Reháková (1998), or in the genus Praecalpionellites, according to Grün \& Blau (1999).

The common dimensions of our specimens are $144-155 \mu \mathrm{m}$ in length and $76-83 \mu \mathrm{m}$ in width. The species ranges from the base of Darderi Subzone to the upper part of the Major Subzone. 


\section{Plate I}

Transmitted light micrographs and drawings of calpionnelids from samples of the Guidaloca section (Western Sicily), in thin sections. Scale bar: $50 \mu \mathrm{m}$.

1a, b) Borzaiella slovenica (BorZA), GDD, 2.15. 2a, b) Longicollaria dobeni (BorZA), GDD, 2.15. 3a, b) Chitinoidella boneti DoBEN, GDD, 2.60. 4a, b) Chitinoidella boneti Doben, GDD, 2.60. 5a, b) Chitinoidella boneti Doben, GDD, 2.60. 6a, b) Dobeniella bermudezi (FurRAzOLA-Bermudez), GDD, 2.60. 7a, b) Dobeniella bermudezi (Furrazola-Bermudez), GDD, 2.60. 8a, b) Dobeniella cubensis (FurRazola-Bermudez), GDD, 2.60. 9) Praetintinnopsella andrusovi Borza, GDD, 3.50. 10) Calpionella alpina LoREnZ, GDD, 3.50. 11) Calpionella alpina LoRENZ spherical form, GDE, 14.50. 12) Calpionella alpina LoRENZ isometric form, GDE, 5.00. 13) Calpionella alpina LoREnz, GDE, 5.00. 14, 15) Calpionella sp., GDE, 9.00. 16) Tintinnopsella carpathica (MurgEAnU-FILIPESCU), GDE, 1.00. 17) Tintinnopsella carpathica (MurgeAnu-FILIPESCU), GDE, 7.50. 18) Tintinnopsella carpathica (MurgEANU-FILIPESCU), GDE, 7.50. 19) Crassicollaria brevis Remane, GDE, 0.00. 20) Crassicollaria brevis Remane, GDE, 0.00. 21) Crassicollaria parvula Remane, GDE, 2.50. 22) Crassicollaria parvula ReMANE, GDE, 2.50. 23) Crassicollaria massutiniana (COLOM), GDE, 0.50. 24) Crassicollaria massutiniana (Colom), GDE, 0.50. 25) Crassicollaria massutiniana (Colom), GDE, 1.50. 26) Crassicollaria colomi Doben, GDE, 1.50. 27) Crassicollaria colomi Doben, GDE, 2.00. 28) Crassicollaria intermedia (DuRAND-Delga), GDE, 0.50. 29) Crassicollaria intermedia (Durand-Delga), GDE, 1.00. 30a, b) Remaniella ferasini (CATAlano), GDE, 4.50. 31a, b) Remaniella ferasini (CATALANo), GDE, 6.00. 32a, b) Remaniella catalonoi Pop, GDE, 4.00. 33) Calpionella sp., GDE, 9.00. 

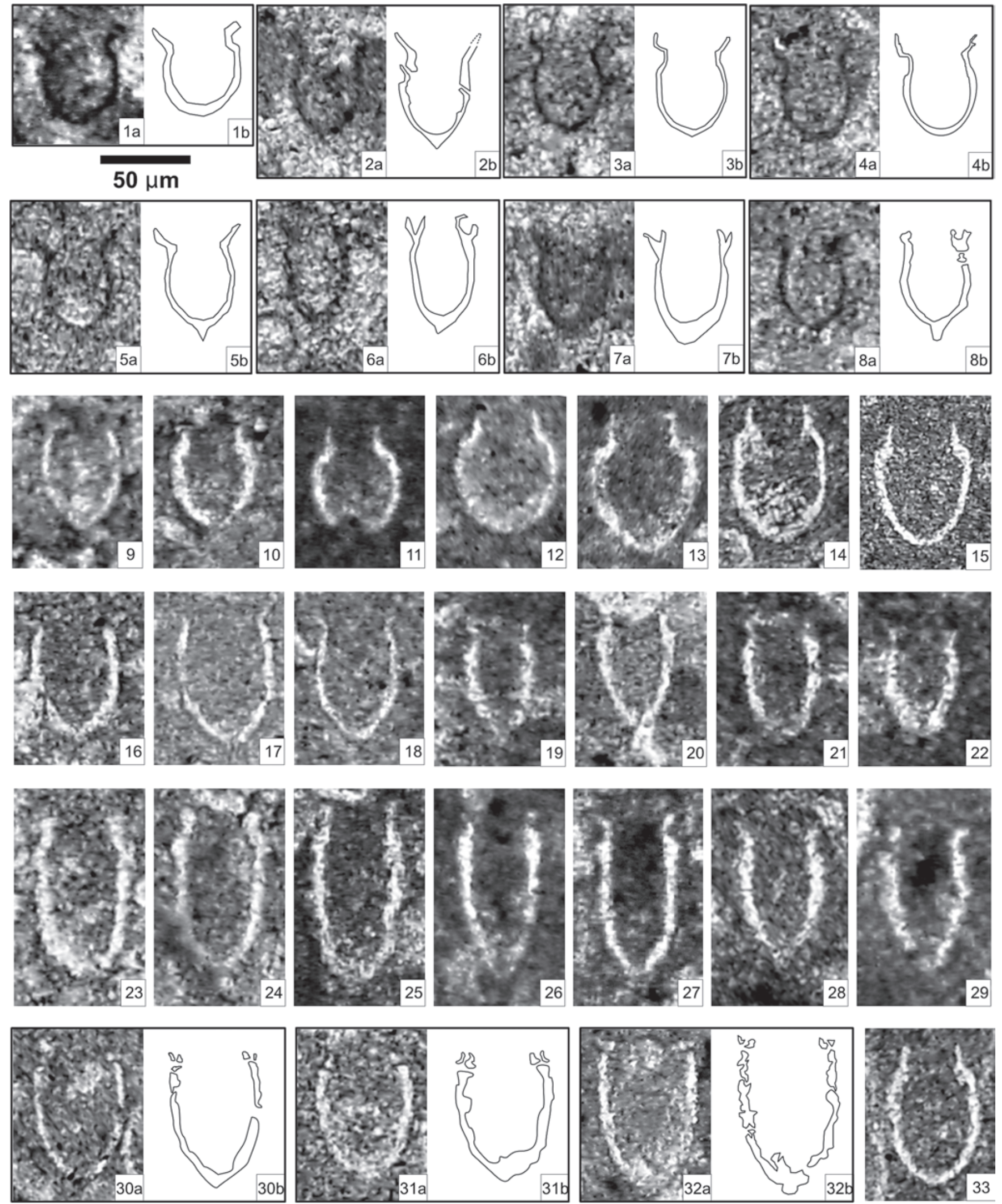


\section{Plate II}

Transmitted light micrographs and drawings of calpionnelids from samples of the Guidaloca section (Western Sicily), in thin sections. Scale bar: $50 \mu \mathrm{m}$.

1) Calpionella elliptica CADISCH, GDE, 14.50. 2) Calpionella elliptica CADISCH, GDE, 18.50. 3a, b) Remaniella duranddelgai PoP, GDE, 9.50. 4a, b) Remaniella catalanoi Pop, GDE, 4.00. 5) Tintinnopsella carpathica (MurgeAnU- FILIPESCU), GL, 8. 6a, b) Remaniella duranddelgai PoP, GDE, 9.50. 7) Remaniella cadischiana (COLOm), GDE, 9.50. 8a, b) Remaniella cadischiana (COLOM), GDE, 9.50. 9a, b) Remaniella colomi PoP, GDE, 19.50. 10) Calpionellopsis simplex (Colom), GDE, 23.50. 11) Calpionellopsis simplex (COLOM), GDE, 23.50. 12) Calpionellopsis oblonga (CADISCH), GDE, 29. 13) Calpionellopsis oblonga (CADISCH), GDE, 29. 14) Tintinnopsella carpathica (Murgeanu-Filipescu), GL, 8. 15) Tintinnopsella carpathica (Murgeanu-Filipescu), GDE, 32. 16) Calpionellites major (Colom), GDE, 38.50. 17a, b) Praecalpionellites murgeanui (Pop), GDE, 33. 18a, b) Sturiella oblonga BorzA, GDE, 23.50. 19a-b) Remaniella borzai Pop, GDE, 12.00. 20) Remaniella filipescui PoP, GDE, 32.00. 21a, b) "Praecalpionellites” dadayi (KNAUER), GDE, 36.50. 22a, b) Remaniella filipescui PoP, GDE, 24.00. 23a, b) Borzaiella atava GRÜN \& BLAU, GDE, 24.00. 


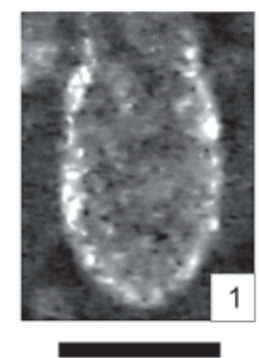

$50 \mu \mathrm{m}$
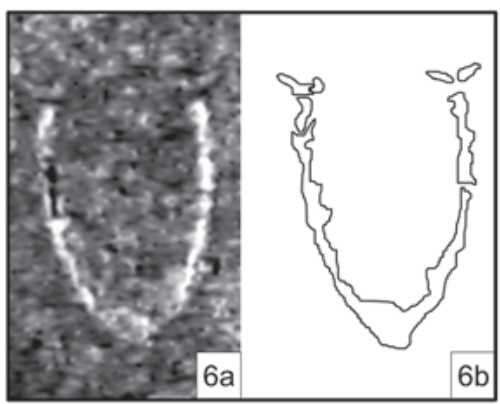

$6 \mathrm{~b}$
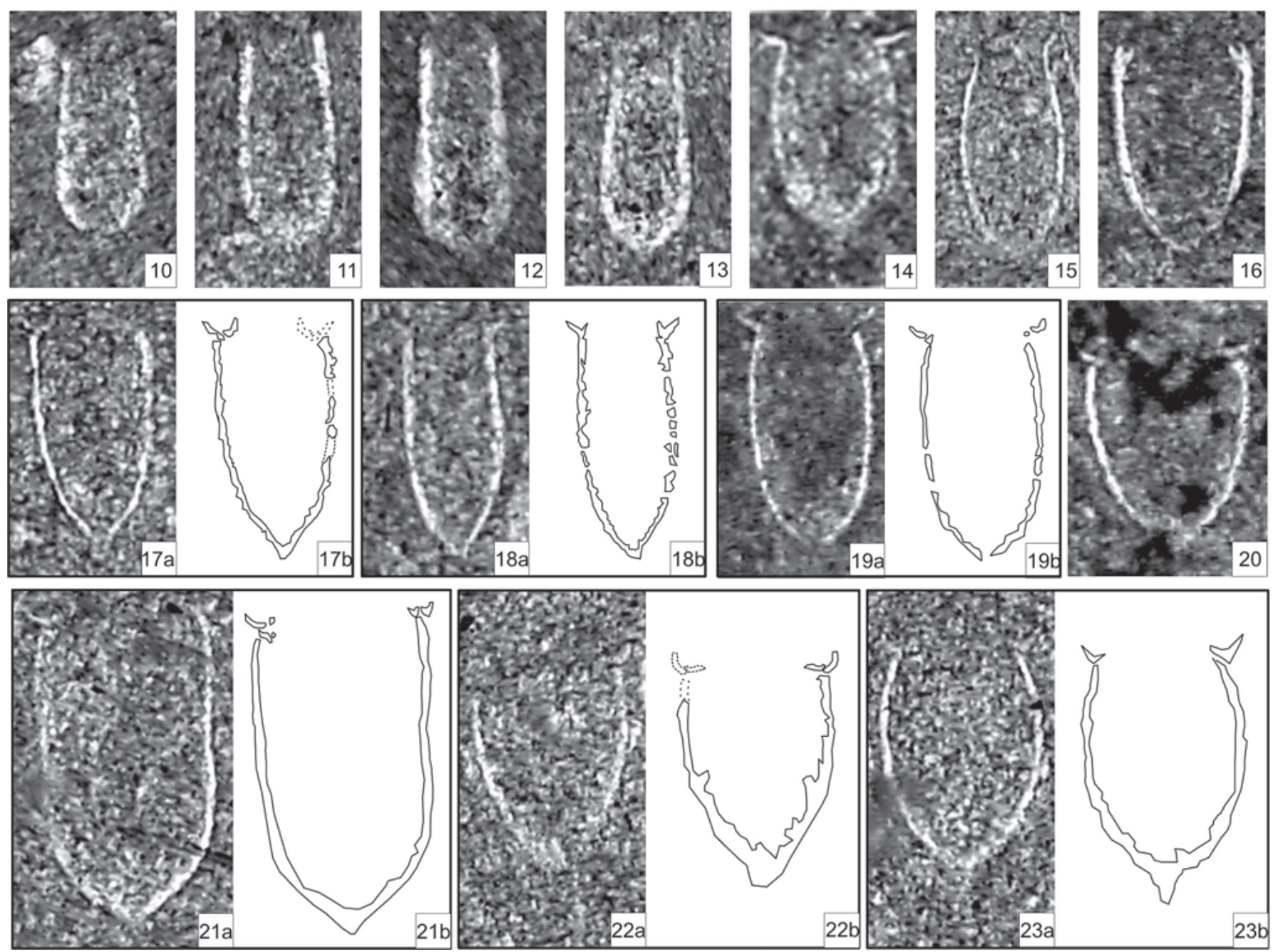


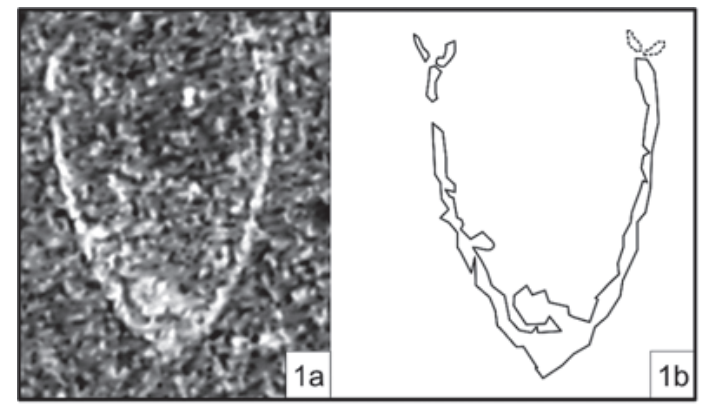

\section{$50 \mu \mathrm{m}$}

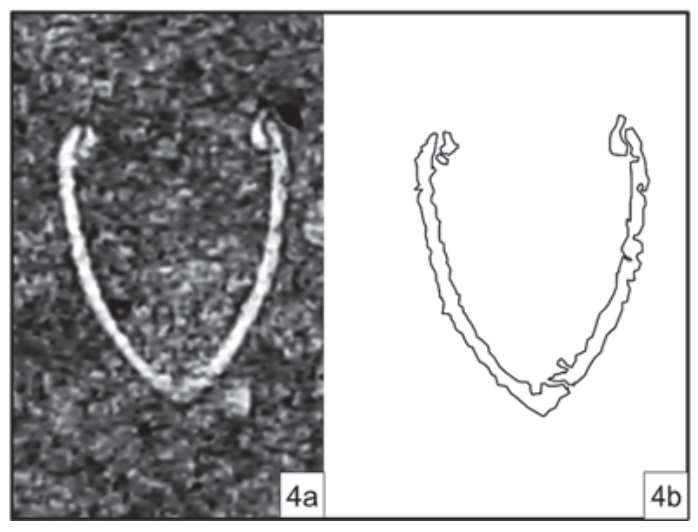

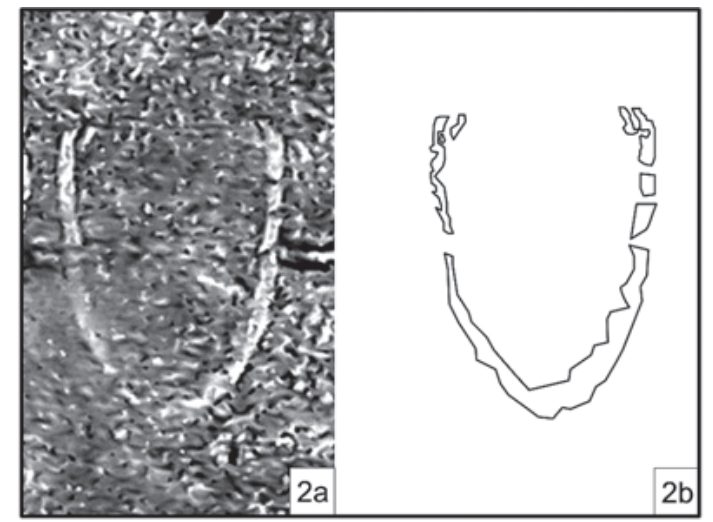
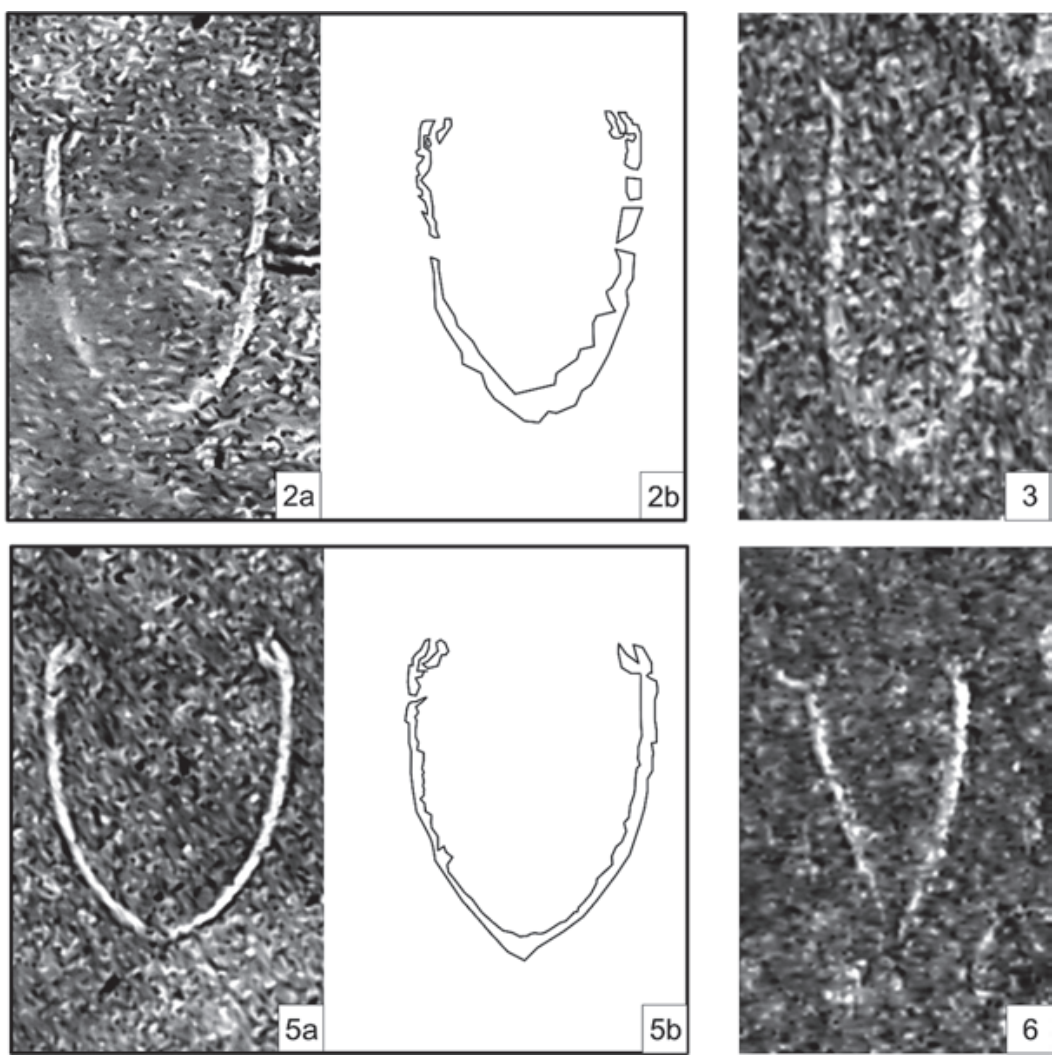

\section{Plate III}

Transmitted light micrographs and drawings of calpionnelids from samples of the Guidaloca section (Western Sicily), in thin sections. Scale bar: $50 \mu \mathrm{m}$.

1a, b) Praecalpionellites murgeanui (Pop), GDE, 36.50. 2a, b) Calpionellites major (COLOM), GL, 6. 3) Tintinnopsella longa (Colom), GDE, 24.00. 4a, b) Calpionellites coronatus (TreJo), GDE, 38.50. 5a, b) Calpionellites darderi (COLOM), GL, 6. 6) Praecalpionellites murgeanui (PoP), GDE, 36.50. 